JGR Oceans

\author{
RESEARCH ARTICLE \\ 10.1029/2020JC016199 \\ Key Points: \\ - High seasonal and interannual \\ variabilities of the Canary Current \\ transport over the African slope \\ - Interannual variability of the \\ Intermediate Poleward \\ UnderCurrent \\ - High interannual variability in the \\ seasonal cycle of the Atlantic \\ Meridional overturning Circulation \\ in the eastern boundary
}

Correspondence to:

A. Hernández-Guerra,

alonso.hernandez@ulpgc.es

Citation:

Casanova-Masjoan, M., Pérez-

Hernández, M. D., Vélez-Belchí, P.,

Cana, L., \& Hernández-Guerra, A.

(2020). Variability of the Canary

Current diagnosed by inverse box

models. Journal of Geophysical

Research: Oceans, 125, e2020JC016199.

https://doi.org/10.1029/2020JC016199

Received 3 MAR 2020

Accepted 30 JUL 2020

Accepted article online 03 AUG 2020

\section{Variability of the Canary Current Diagnosed by Inverse Box Models}

\author{
M. Casanova-Masjoan ${ }^{1}$ (D) M. D. Pérez-Hernández ${ }^{1} \mathbb{D}$, P. Vélez-Belchí $^{2}$ (D) L. Cana ${ }^{1}$ iD, and \\ A. Hernández-Guerra ${ }^{1}$ iD \\ ${ }^{1}$ Unidad Océano y Clima, Instituto de Oceanografía y Cambio Global, CSIC, Universidad de Las Palmas de Gran Canaria \\ Las Palmas de Gran Canaria, Spain, ${ }^{2}$ Centro Oceanográfico de Canarias, Instituto Español de Oceanografía, Santa Cruz de \\ Tenerife, Spain
}

Abstract Four hydrographic cruises carried out between $\sim 26.5$ and $31^{\circ} \mathrm{N}$ in the eastern North Atlantic Subtropical Gyre in fall (2016 and 2017) and spring (2017 and 2018) are used to identify water masses and infer oceanic circulation. Geostrophic velocities are initially adjusted by referencing them to data from a Lower Acoustic Doppler Current Profiler (LADCP) and later to velocities estimated with an inverse box model. The distribution of the intermediate water masses (700 to 1,400 $\mathrm{m}$ depth) varies seasonally. Antarctic Intermediate Water (AAIW) comprises the largest contributor to the seasonal cycle in the intermediate water masses. Circulation of the Canary Current (CC) differs in fall and spring. In fall, the CC flows southward through the western islands and recirculates south of the archipelago, subsequently flowing northward through the passage between the eastern islands and Africa. North of Lanzarote, the recirculated $\mathrm{CC}$ intensified as it is joined by a southeasterly branch of the CC north of Lanzarote. In spring, the net transport of the $\mathrm{CC}$ is southward. High interannual variability in mass transport is evident in both spring and fall as a result of the position of the current, with its easternmost (westernmost) position found in spring (fall) 2018 (2016). At intermediate levels, highly variable northward/southward transport is apparent in fall over the African slope, with the Intermediate Poleward Under Current (IPUC) only present in 2017.

Plain Language Summary The Canary Current is part of the eastern boundary of the North Atlantic Subtropical Gyre as well as the upwelling system off NorthWest Africa. Its location plays a major role in the Atlantic Meridional Overturning Circulation, which controls the global climate. Therefore, we have studied the Canary Current. Its circulation pattern and its seasonal and interannual variability have been inferred using data from four hydrographic cruises (two carried out in fall and two in spring) around the region of the Canary Islands. From these cruises we have computed the mass transport of the current and identified the water masses present on it. The results show a high seasonal variation in the intermediate water masses (those on the depth range from 700 to $1,400 \mathrm{~m}$ depth). The mass transport of the current also shows a seasonal variability at surface levels ( $<700 \mathrm{~m}$ depth) and at intermediate levels. The current flows southward through the islands and the passage between the islands and Africa in spring, but in fall, the $\mathrm{CC}$ reverses south of Fuerteventura and flows northward through the passage between the archipelago and Africa. Interannually, the mass transport also presents differences, being higher in fall 2017 and spring 2018.

\section{Introduction}

The eastern boundary of the North Atlantic Subtropical Gyre presents three main patterns driving the circulation variability: the Canary Current (CC), the Intermediate Poleward Undercurrent (IPUC), and the Northwest Africa coastal upwelling jet. The southward flowing CC links the Azores Current (AC) with the westward North Equatorial Current (NEC; Hernández-Guerra et al., 2010; Pérez-Hernández et al., 2013). The CC was first studied during the 1980s using historical data (Stramma \& Schott, 1999; Stramma \& Siedler, 1988). These studies determined that the CC shifts seasonally, approaching the African coast during summer and flowing through the western islands in winter. Since the end of the 1990s, the CC has been characterized using moorings and hydrographic data collected during several cruises carried out in the Canary Islands region (Fraile-Nuez et al., 2010; Hernández-Guerra et al., 2001, 2002, 2005, 2017; Machín et al., 2006). These authors have described the main path of the CC through the Canary Islands, including its reversal trough the Lanzarote Passage (LP) in fall.
(C)2020. American Geophysical Union. All Rights Reserved. 

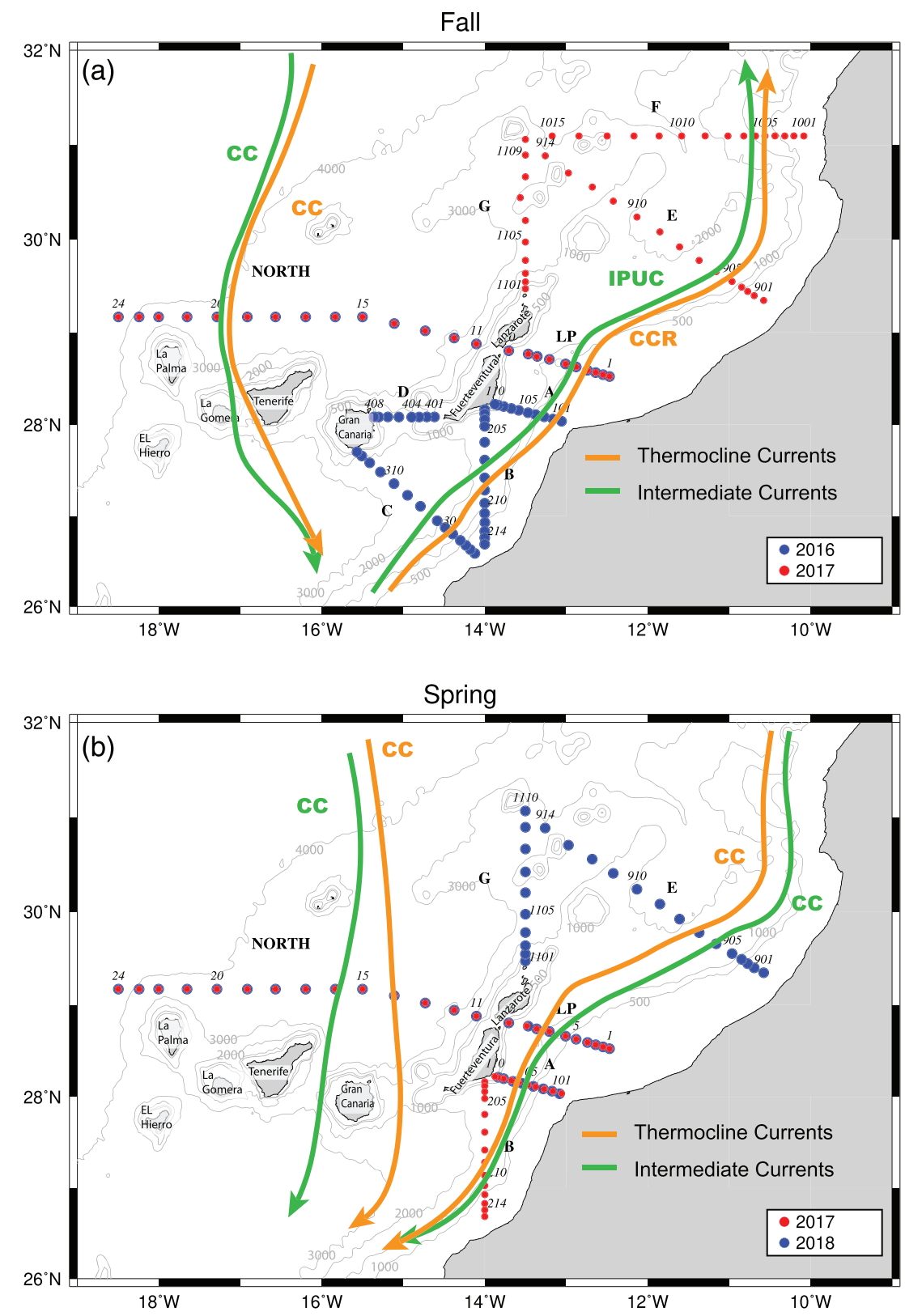

Figure 1. Location of the hydrographic stations at each cruise. (a) Map of stations occupied during fall cruises. The blue dots correspond to 2016 and the red dots to 2017. (b) Same as (a) for spring stations. The red dots represent 2017 and the blue dots 2018. Names of transects are indicated by North, LP (Lanzarote Passage), A, B, C, D, E, F, and G. The gray lines represent the bathymetry from ETOPO1 (Amante \& Eakins, 2009). The orange and green arrows are a schematic representation of the circulation in the area at thermocline and intermediate layers, respectively. The labels represented are the Canary Current (CC), Canary Current Recirculation (CCR) and Intermediate Poleward UnderCurrent (IPUC).

The CC carries North Atlantic Central Water (NACW) southward throughout the entire archipelago (Machín et al., 2006), with the magnitude and transport of this water mass varying temporally and spatially. Previous estimates, derived using an inverse box model approach, showed that the lowest NACW transport occurs in spring, when the CC transports $-2.8 \pm 1.0 \mathrm{~Sv}\left(1 \mathrm{~Sv}=10^{9} \mathrm{~kg} / \mathrm{s}\right.$, with positive transports towards the east/north and negative to the west/south) and approaches the African coast. In contrast, highest transport occurs in fall $(-4.5 \pm 1.2 \mathrm{~Sv})$, when the CC flows through the westernmost islands (Machín et al., 2006). Pérez-Hernández et al. (2013) confirmed that this westwards shift in the current, documenting flow beyond the western islands. However, the seasonality of the $\mathrm{CC}$ in the oceanic region also differs from that of the 
African slope region, with differences attributed to variability in flow dynamics in both regions (Fraile-Nuez \& Hernández-Guerra, 2006; Pelegrí et al., 2005). The CC in the oceanic region is forced by the curl of the wind stress, with dynamics largely explained by Sverdrup theory (Fraile-Nuez \& Hernández-Guerra, 2006; Mason et al., 2011; Roemmich \& Wunsch, 1985). On the other hand, the CC at the LP presents an average southward flow of $-0.6 \pm 0.1 \mathrm{~Sv}$ (Machín et al., 2006), recirculating northward through the passage between the islands and Africa in fall. The recirculation of the CC transports $1.7 \pm 0.5 \mathrm{~Sv}$ at $\sim 27^{\circ} \mathrm{N}$ and increases to $2.9 \pm 0.5 \mathrm{~Sv}$ at the LP (Hernández-Guerra et al., 2017). The reversal of the CC at the LP in fall is thought to be related either to upwelling dynamics (Hernández-Guerra et al., 2002; Machín \& Pelegrí, 2016), offshore separation of the CC (e.g. Hernández-Guerra et al., 2003), or to mesoscale activity south of the islands (Hernández-Guerra et al., 1993; Mason et al., 2012; Pacheco \& Hernández-Guerra, 1999; Pérez-Herández et al., 2015). In the upwelling systems, a jet separates upwelled waters from offshore waters (Benítez-Barrios et al., 2011). When the upwelling favorable winds weaken, the jet slows down and the poleward current arises beneath (Hernández-Guerra et al., 2002).

At intermediate levels ( 700-1,400 m depth), two water masses are found in the vicinity of the Canary archipelago: the Antarctic Intermediate Water (AAIW) from 700 to 1,100 $\mathrm{m}$ depth, and the Mediterranean Water (MW) from about 900 to 1,400 m depth (Fraile-Nuez et al., 2010; Hernández-Guerra et al., 2003). The flow of the intermediate waters in the CC region is southward throughout the islands and the LP, except in fall when the IPUC transports AAIW northward through the LP and west of Lanzarote (Hernández-Guerra et al., 2017; Pérez-Herández et al., 2015). The IPUC can reach up to $32.5^{\circ} \mathrm{N}$ flowing along the $27.5 \mathrm{~kg} / \mathrm{m}^{3}$ isoneutral (Machín \& Pelegrí, 2009; Machín et al., 2010).

The main purpose of this study is to provide a more detailed estimate of the CC circulation in fall and spring in the region spanning the eastern Canary Islands and the African coast, in the latitude range $\sim 26.5^{\circ}-31^{\circ} \mathrm{N}$ (Figure 1). To achieve this goal, several inverse box models are applied to data collected during four cruises. This study is described as follows: the data are introduced in section 2 . In section 3, the water mass distribution in the area is described through $\theta-S$ diagrams and vertical sections of salinity. Is section 4 , we present unbalanced mass transport. The inverse box model is described in section 5 , and the final geostrophic mass transport is shown in section 6 . We finish with the discussion and conclusions in section 7.

\section{Data}

Data were collected during four cruises onboard the R/V Angeles Alvariño. Two cruises were carried out in fall and included 70 hydrographic stations from 31 October to 11 November 2016 and 63 hydrographic stations from 10 October to 20 October 2017, while the two spring cruises included 48 hydrographic stations from 19 April to 2 May 2017 and 56 hydrographic stations from 10 to 21 April 2018. The hydrographic sections sampled waters between $\sim 26.5$ and $31^{\circ} \mathrm{N}$ (Figure 1). These sections include a zonal section from west of La Palma to the northeast of Fuerteventura (North section) and up to eight shorter transects sampled between the eastern islands and the African coast (sections A to G and LP, Figure 1). The sections between the eastern islands and the African coast enable us to use inverse box models to estimate the absolute geostrophic mass transport. At each hydrographic station, conductivity, temperature, and depth (CTD) were measured with a Seabird 911+ CTD equipped with redundant temperature and salinity sensors. A 150-kHz downward looking workhorse Lowered Acoustic Doppler current profiler (LADCP) provide a velocity profile at each station. LADCP data were processed according to Fischer and Visbeck (1993). Data were acquired from the surface to $10 \mathrm{~m}$ above the bottom. The distance between stations was typically about $5 \mathrm{~km}$ for the stations over the African slope and $\sim 25 \mathrm{~km}$ for the open ocean stations west of $14^{\circ} \mathrm{W}$.

Wind data are estimated using the Weather Research and Forecasting (WRF) model (version 3.9.1), developed at the National Center for Atmospheric Research. In contrast with other climatological models, this model has the advantage of obtaining wind data in high temporal and spatial resolution in order to resolve the orographic perturbation of the wind as it flows through the islands and the wind variability during the cruise. A complete description of this model can be found in Skamarock et al. (2008). Data from the operational analysis performed every $6 \mathrm{hr}$, at $1^{\circ}$ horizontal resolution at the National Center for Environmental Prediction (NCEP final analysis) were used as initial and boundary conditions for the simulations. We set a horizontal grid spacing of $0.125^{\circ}$ and 50 terrain-influenced coordinate levels for our simulations (Cana et al., 2020). Model output spanning our period of field sampling, including east-west and 

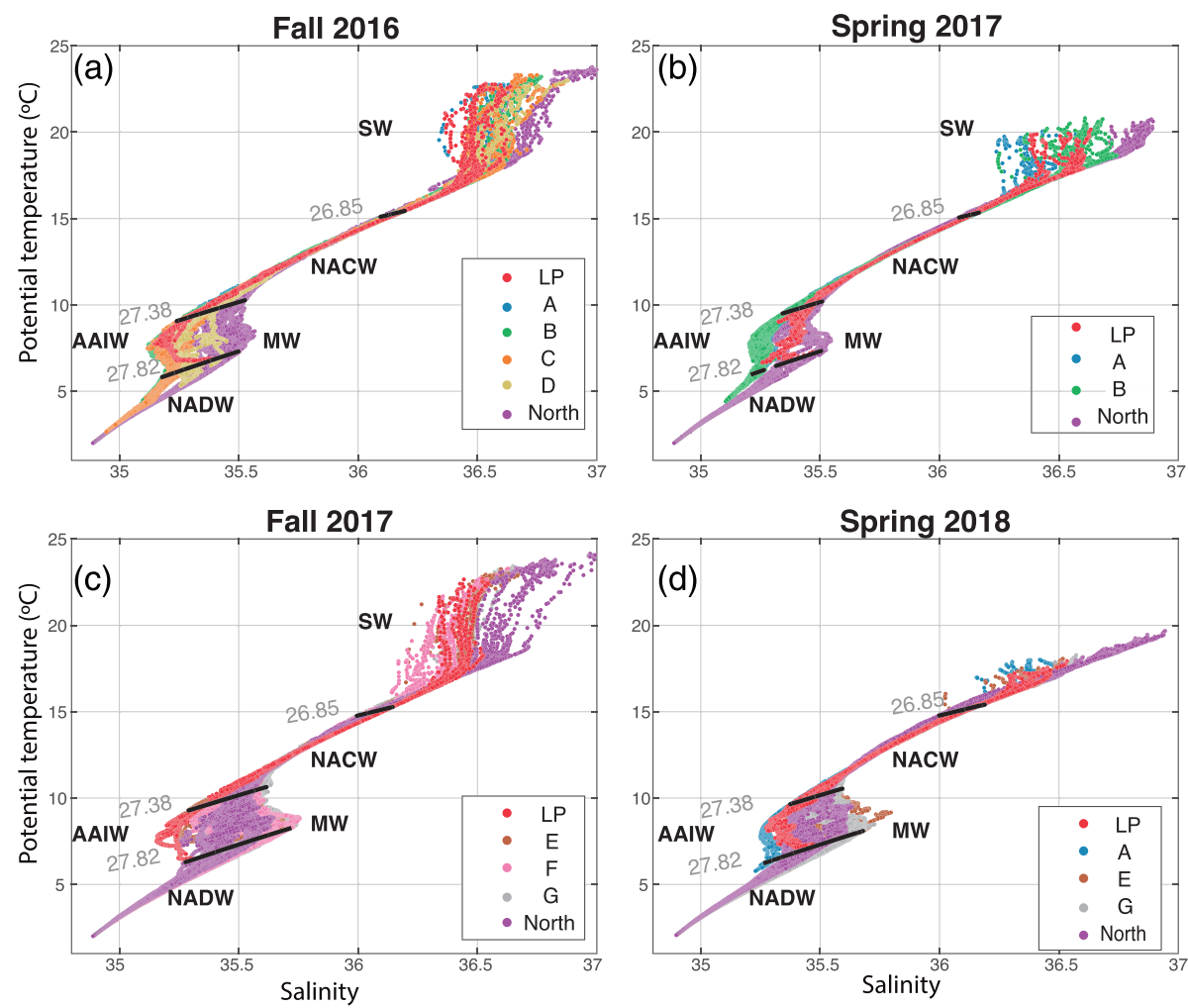

Figure 2. $\theta-S$ diagrams for the four cruises: (a) fall 2016, (b) spring 2017, (c) fall 2017, and (d) spring 2018. The thick black lines correspond to the isoneutrals, which approximately divide the water column into surface $\left(\gamma^{n}<26.85 \mathrm{~kg} / \mathrm{m}^{3}\right)$, central $\left(26.85>\gamma^{n}>27.38 \mathrm{~kg} / \mathrm{m}^{3}\right)$, intermediate $\left(27.38>\gamma^{n}>27.82 \mathrm{~kg} / \mathrm{m}^{3}\right)$, and deep $\left(\gamma^{n}>27.82 \mathrm{~kg} / \mathrm{m}^{3}\right)$ water masses. Isoneutral values are indicated in gray. Colors correspond to transects (see Figure 1). Water masses are indicated in black, including Surface Waters (SW), North Atlantic Central Water (NACW), Antarctic Intermediate Water (AAIW), Mediterranean Water (MW), and North Atlantic Deep Water (NADW).

north-south wind velocities, measured at $10 \mathrm{~m}$ (U10 and V10, respectively). V10 and U10 are used in this study to estimate the Ekman transport, during the period of the cruise, in the first layer of the inverse box model.

\section{Water Mass Distribution}

Temperature-salinity $(\theta-S)$ diagrams are used to identify water masses and their vertical distributions from isoneutrals (Figure 2). These include Surface Water (SW), NACW, AAIW, MW, and North Atlantic Deep Water (NADW). SW is present above the seasonal thermocline, extending from the surface to $\gamma^{n}=26.85 \mathrm{~kg} / \mathrm{m}^{3}$ (approximately 80 and $320 \mathrm{~m}$ depth). This water is characterized by scattered potential temperature and salinity values due to seasonal heating, evaporation, and the influence from the upwelling filaments (Borges et al., 2004; Nykjær \& Van Camp, 1994; Van Camp et al., 1991). Below the seasonal thermocline, the NACW extends to $27.38 \mathrm{~kg} / \mathrm{m}^{3}$ isoneutral $\left(\gamma^{n}\right)$ located at approximately $700 \mathrm{~m}$ depth (Hernández-Guerra et al., 2005). NACW is identified in the $\theta$-S diagram by a straight relationship between potential temperature and salinity in the range of 10 to $17^{\circ} \mathrm{C}$ and 35.6 to 36.7, respectively (Harvey, 1982; Tomczak, 1981). Two different water masses are identified at intermediate levels, between $\gamma^{n}=27.38$ and $27.82 \mathrm{~kg} / \mathrm{m}^{3}(\sim 700-1,400 \mathrm{~m}$ depth$)$, including the cooler and fresher AAIW $(35.1<\mathrm{S}<35.4)$, and the warmer and saltier MW $(35.4<$ S $<35.8$; Hernández-Guerra et al., 2001).

Figure 3 shows the vertical distribution of the two intermediate water masses present in the area in fall (left column) and spring (right column). For those transects repeated during more than one season (LP and A) the transect with most AAIW content is shown. From north to south, a core of MW is observed on the western side of the E and F transects (only E in spring) and a core of AAIW on the eastern side (Figures 3a, 3b, 


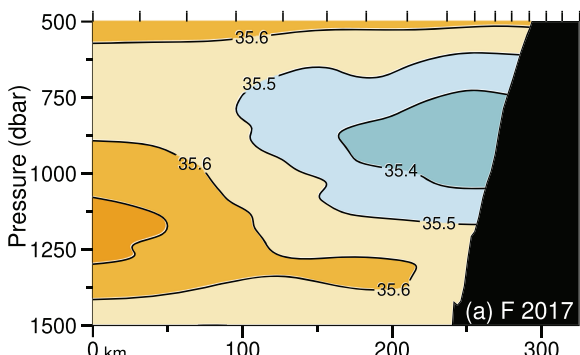

$\begin{array}{llllllll}35.0 & 35.2 & 35.3 & 35.4 & 35.5 & 35.6 & 35.7 & 37.0\end{array}$
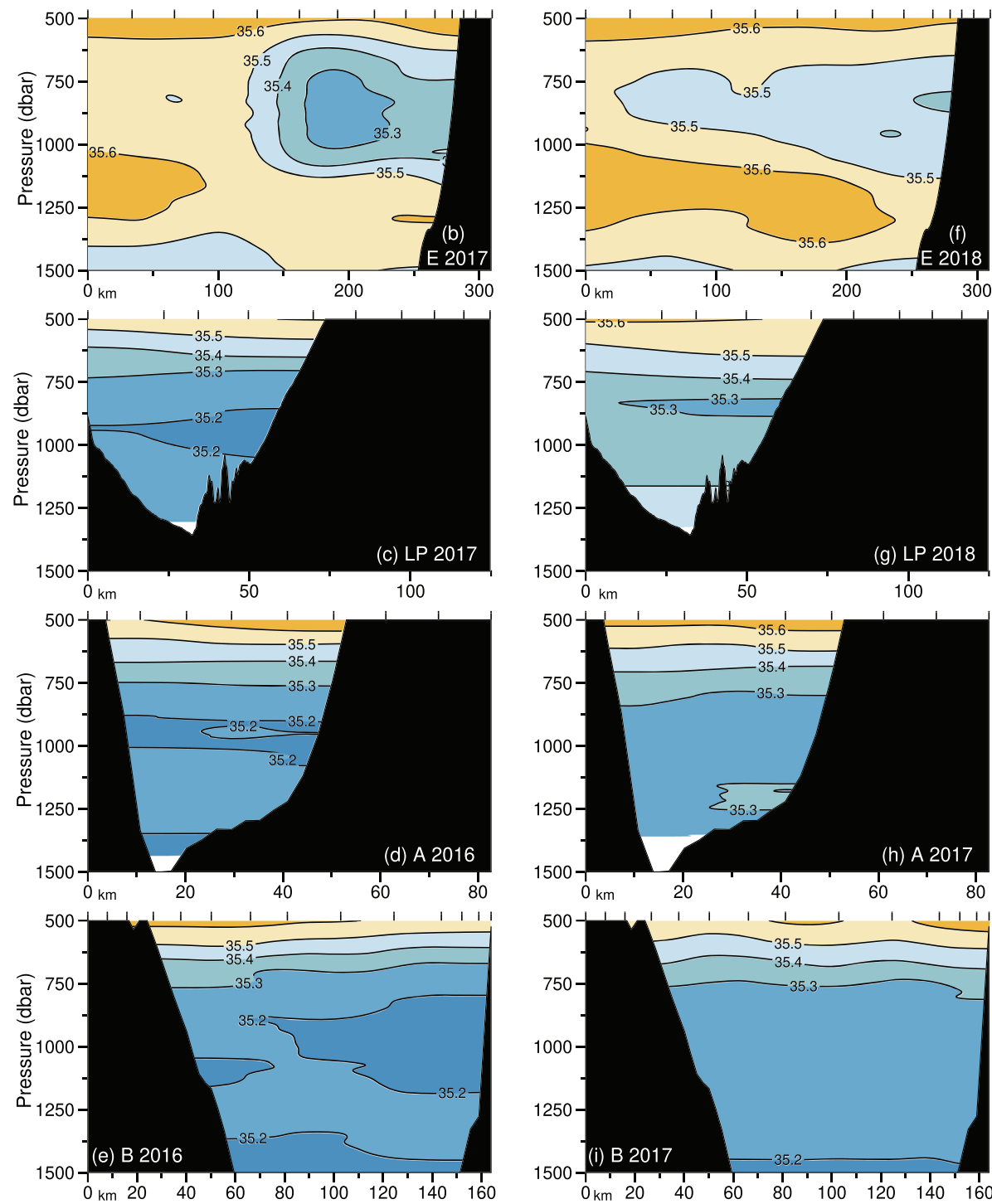

Figure 3. African slope salinity cross sections, focusing on intermediate levels (500-1,500 $\mathrm{m}$ depth) in fall (a-e) and spring (f-i). Section F (a), section E (b and f), and section LP (c and g) for fall 2017 and spring 2018 cruises, respectively. Panels (d) and (h) correspond to section A, and panels (e) and (i) correspond to section B for fall 2016 and spring 2017 cruises, respectively. Mediterranean Water (MW) and Antarctic Intermediate Water (AAIW) are labeled in each of the sections where they are observed.

and 3f). From LP to B (Figures 3c-3e and 3g-3i), the signal of MW could not be traced, while the AAIW signature is always present and stronger than in sections E and F. Overall, the salinity of AAIW is lower in fall than in spring. Minimum salinity values of AAIW are 35.2 and 35.3 in fall and spring, respectively. For transect E, the western MW core seen in fall expands all the way to the east in spring (Figure $3 f$ vs. Figure 3b). 


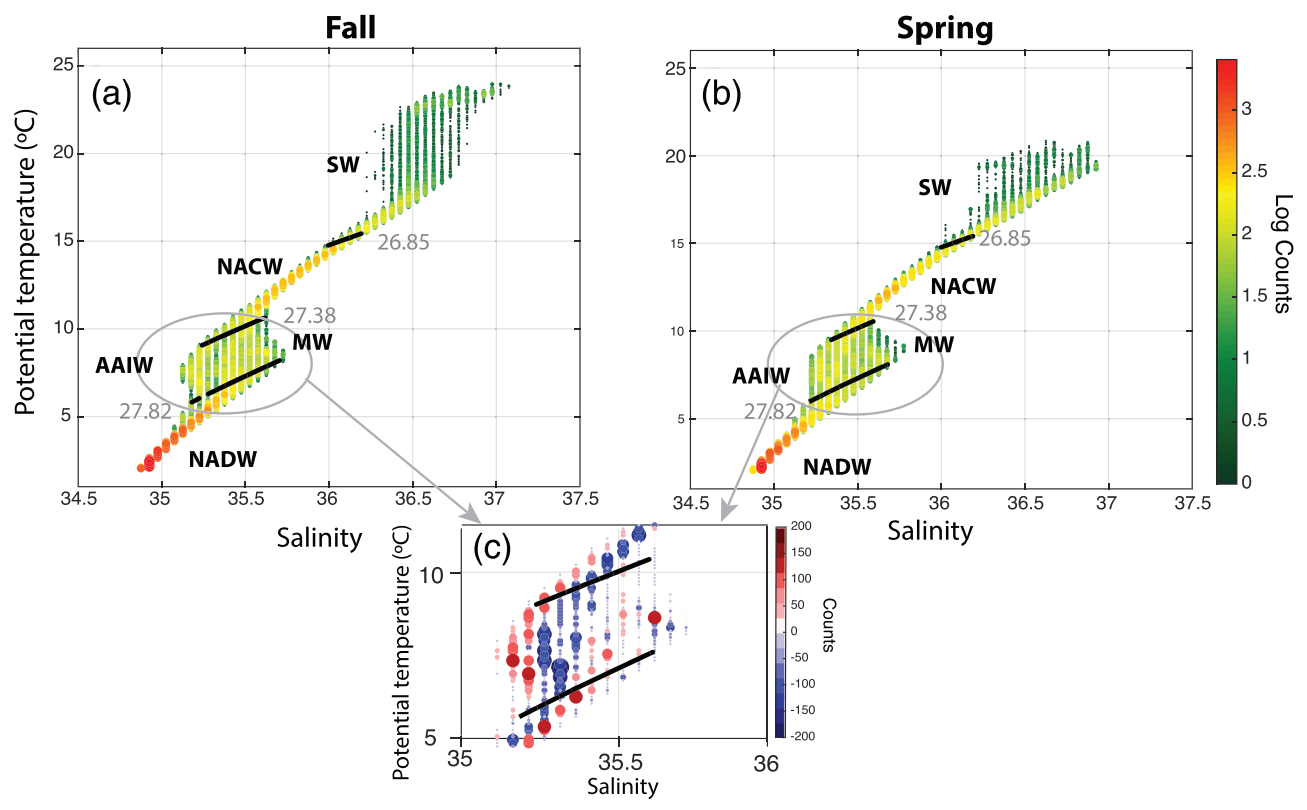

Figure 4. Volumetric $\theta-S$ diagrams for (a) fall and (b) spring. The colors represent the logarithm of the number of counts per grid point defined in the diagram. Marker size indicate magnitude of counts. (c) Difference in number of counts (non-logarithmic) of the volumetric $\theta-S$ diagrams of fall and spring (fall-spring). Positive values (red) indicate more abundance in fall, while negative values (blue) indicate more abundance in spring.

To quantify the abundance of each intermediate water mass in fall and spring, volumetric $\theta$-S diagrams are plotted separately only for sections repeated in fall and spring (excluding F, D, and C). Figures $4 \mathrm{a}$ and $4 \mathrm{~b}$ show AAIW reaching its lowest salinity values in fall and MW reaching its highest salinity values in spring. From these volumetric $\theta-S$ diagrams, a seasonal difference (fall minus spring) of counts per grid point is derived and represented in Figure 4c. This figure demonstrates the seasonality of the intermediate layer, where AAIW dominates in fall (red colors in Figure 4c), while MW dominates in spring (blue colors). AAIW is still present in spring (blue dots) but is saltier than in fall (red dots). Despite the greater abundance of MW in spring than in fall, the number of MW counts at each grid point is small compared to AAIW. This implies that AAIW is the largest contributor to the seasonal cycle of the intermediate water masses surrounding the Canary Islands.

In addition, relative distributions of MW and AAIW changes interannually between 2016 and 2018, particularly during spring cruises (Figures $2 \mathrm{~b}$ and 2d). In spring 2017, the LP shows neither a strong AAIW nor MW signal, with both water masses very mixed, while in 2018 the LP and A sections show greater AAIW content (Figures 2b-2d). On the other hand, the North section shows more MW in 2018 than in 2017 (Figures 2b-2d). In fall, there is also difference between occupations of the LP/North section, with AAIW/MW reaching more extreme values in 2017 than in 2016 (Figures 2a-2c).

Finally, NADW is observed in deepest waters below $\gamma^{n}=27.82 \mathrm{~kg} / \mathrm{m}^{3}$, with the potential temperature and salinity in the range of $2.5-6.4^{\circ} \mathrm{C}$ and $34.9-35.5$, respectively. NADW is the most homogenous and abundant water mass in both seasons and across all cruises (Figures $4 \mathrm{a}$ and $4 \mathrm{~b}$ ).

\section{Unbalanced Mass Transport}

Prior to applying the inverse box model, we estimate the initial geostrophic velocity and transport at each pair of stations using the thermal wind equation. Two different levels of no motion are chosen depending on the location and depth of the station pair. At each station pair over the African slope where steep topography is found, the level of no motion is set to $\gamma^{n}=27.38 \mathrm{~kg} / \mathrm{m}^{3}$ ( $700 \mathrm{~m}$ depth), between the NACW and AAIW layers. This reference layer has been used in previous studies (Hernández-Guerra et al., 2001, 2005; Pérez-Hernández et al., 2013). For the deepest stations (transects E, F, and G and North) the level 
Table 1

Neutral Density Levels Used in the Analysis, Following HernándezGuerra et al. (2017)

\begin{tabular}{lcl}
\hline Layer & $\gamma^{n}$ & Water mass \\
\hline 1 & Surface-26.44 & SW \\
2 & $26.44-26.85$ & SW \\
3 & $26.85-27.162$ & NACW \\
4 & $27.162-27.38$ & NACW \\
5 & $27.38-27.62$ & AAIW \\
6 & $27.62-27.82$ & AAIW/MW \\
7 & $27.82-27.922$ & NADW \\
8 & $27.922-27.975$ & NADW \\
9 & $27.975-28.008$ & NADW \\
10 & $27.008-28.044$ & NADW \\
11 & $28.044-28.072$ & NADW \\
12 & $28.072-28.0986$ & NADW \\
13 & $28.0986-$ Bottom & NADW \\
\hline
\end{tabular}

Note. Thermocline levels are defined as layers 1 to 4 , intermediate levels as layers 5 and 6, and deep levels as layers 7 to 13 .

Abbreviations: AAIW: Antarctic Intermediate Water; MW: Mediterranean

Water; NACW: North Atlantic Central Water; NADW: North Atlantic Deep Water; SW: Surface Water. of no motion chosen is $\gamma^{n}=27.975 \mathrm{~kg} / \mathrm{m}^{3}(\sim 1,700 \mathrm{~m})$ following Hernández-Guerra et al. (2017) and Vélez-Belchí et al. (2017). For station pairs shallower than the reference level, the bottom is considered the reference level. We divide the water column into 13 neutral density layers (see Table 1) following Hernández-Guerra et al. (2017). The thermocline corresponds henceforth to layers 1 to 4 , intermediate waters to layers 5 and 6 , and deep waters to layers 7 to 13 (Table 1). The initial velocities at the reference level are adjusted using LADCP-derived velocities using a procedure described in Comas-Rodríguez et al. (2010).

The integrated mass transport per neutral density layer using the LADCP-adjusted reference velocities at each transect and for each of the 4 cruises is shown in Figure 5. The highest transport takes place in the thermocline and intermediate layers. The transport of the transects along the passage between the islands and African coast shows different patterns in fall and spring (A, B, C, E, F, and LP). In the thermocline the overall transport is southward in spring and northward in fall, indicating the presence of the CC flowing southward in spring and reversing in fall (Hernández-Guerra et al., 2001, 2002, 2017).

\section{Inverse Box Model}

We use sections bounding our region of interests to estimate absolute geostrophic transport using an inverse box model. This model provides an efficient method to adjust the velocities at the reference level, already provided by the LADCP, in order to achieve mass balance in each of the different enclosed volumes
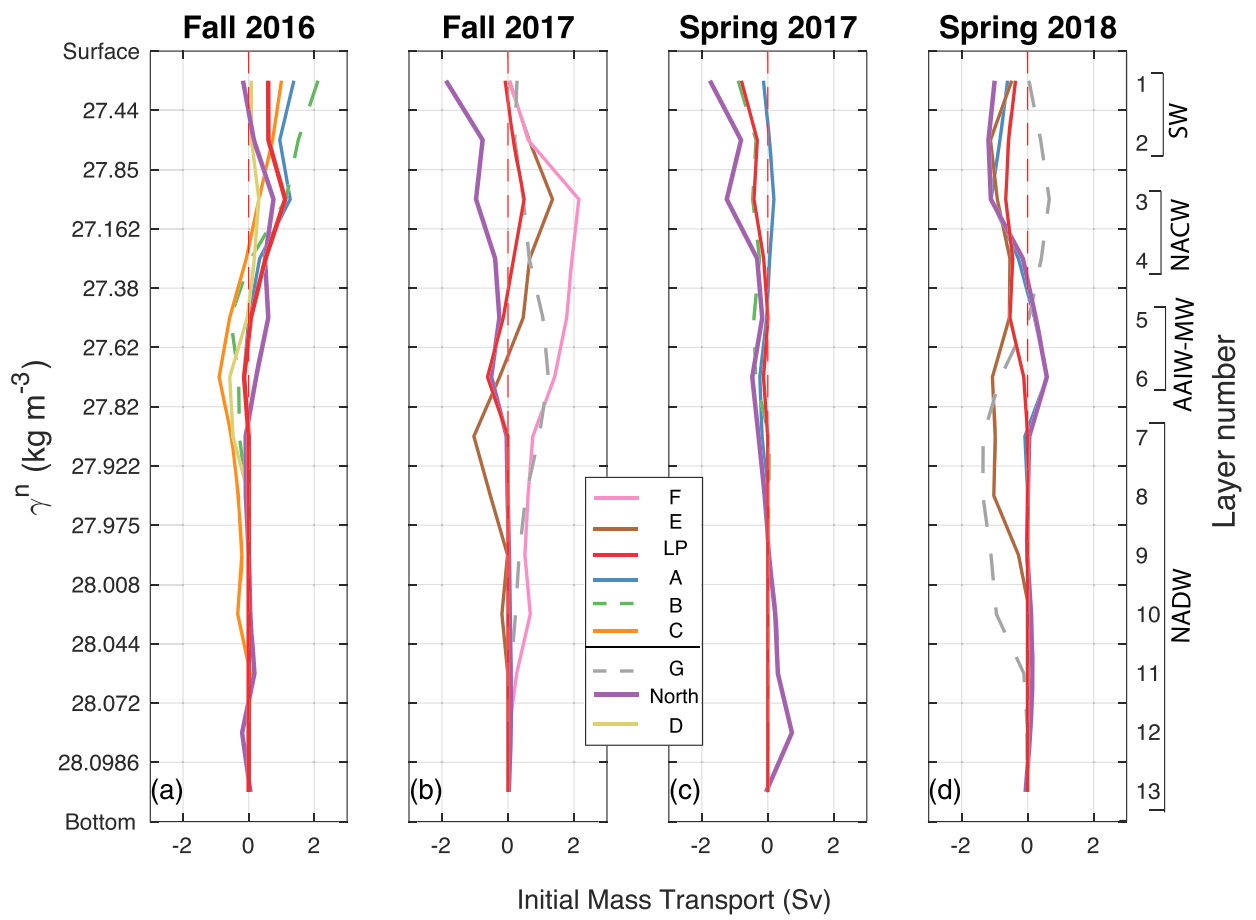

Figure 5. Integrated mass transport per isoneutral layer using the unbalanced geostrophic velocities adjusted with LADCP velocities. The four panels correspond to the transport in (a) fall 2016, (b) fall 2017, (c) spring 2017, and (d) spring 2018. Positive/negative sign indicates eastwards/westward or northward/southward flow. The line colors indicate north-south transects for each cruise. The solid lines stand for northward/southward flow and dashed lines for eastward/westward flow. The back line in the legend separates the transects done on the African Slope from the others. The labels of the water masses are shown next to the layer number to which they correspond. 
Table 2

Inverse Model Characteristics for Each of the Cruises, Including the Number of Station Pairs, the Number of Equations, the Number of Unknowns, and the Transects that Shape Each Box

\begin{tabular}{lcccc}
\hline & Fall 2016 & Fall 2017 & Spring 2017 & Spring 2018 \\
\hline Station pairs & 51 & 47 & 31 & 39 \\
Equations & 42 & 28 & 28 & 28 \\
Unknowns & 56 & 51 & 34 & 43 \\
Box 1 & LP-A & F-E & LP-A & E-G-LP \\
Box 2 & A-B & E-LP-G & A-B & LP-A \\
Box 3 & B-D-C & - & - & - \\
\hline
\end{tabular}

Note. The capital letters listed in the table correspond to the names of the transects shown in figure 1. seen in Figure 1. Our inverse model also adjust the Ekman transport estimated from the wind data during the period of the cruise, as in Casanova-Masjoan et al. (2018), Hernández-Guerra et al. (2019), and Hernández-Guerra and Talley (2016; Alonso Hernández-Guerra et al., 2014). Computed Ekman transport per transect is very small (i.e., negligible) except in fall and spring 2017 in the LP (0.1 Sv and $-0.1 \mathrm{~Sv}$, respectively), section A in spring 2018 (-0.2 Sv), section $\mathrm{E}$ in spring and fall (0.2 Sv and $-0.2 \mathrm{~Sv}$, respectively), and in section $F$ and $G$ in both fall and spring $(0.2 \mathrm{~Sv}$ and $-0.1 \mathrm{~Sv}$, respectively).

The inverse box model is applied to each cruise individually, as the regions (boxes) encompassed by the hydrographic sections shown in Figure 1 vary for each cruise. Differences among models lie in the number of equations and uncertainties, which in turn depend on the number of boxes enclosed per cruise. Each box includes a mass conservation equation per neutral density layer shown in Table 1 (Equations 1 to 13) as well as the total mass conservation (Equation 14) with the adjustment of Ekman transport included in the shallowest layer and the total mass conservation equations. The configuration of each inverse box model, including the transects shaping each box, number of equations of each model, and the number of unknowns, are shown in Table 2.

The inverse model solves the following equation:

$$
\iint \rho b d x d z=-\iint \rho V_{r} d x d z+T_{\mathrm{Ek}}
$$

where $\rho$ corresponds to the density of the ocean, $x$ and $z$ are the horizontal and vertical coordinates of the box respectively, $b$ is the adjusted velocities at the reference level of each station pair, $V r$ is the relative velocity from the thermal wind equations, and $T_{\mathrm{Ek}}$ is the Ekman Transport.

(a) Fall 2016

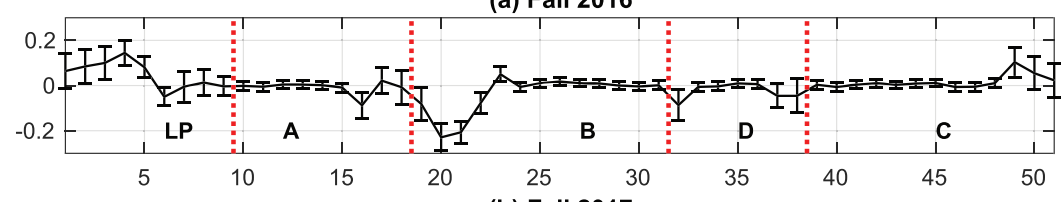

(b) Fall 2017

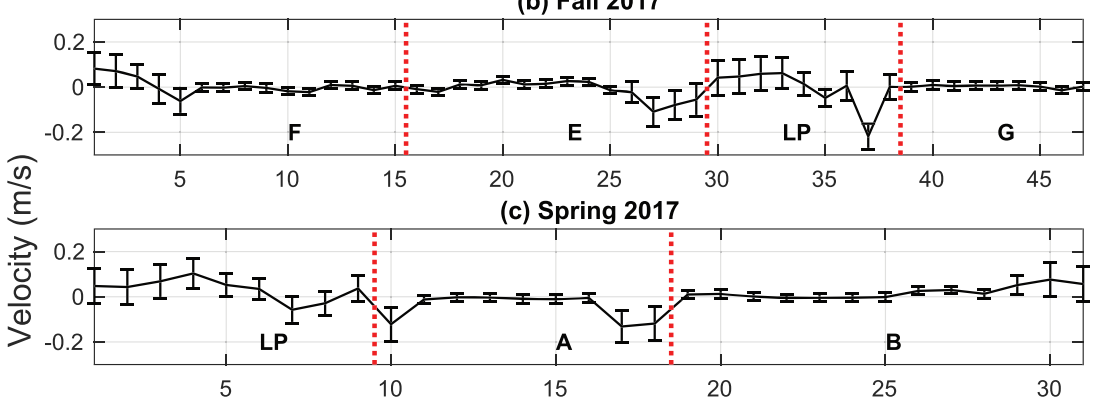

(d) Spring 2018

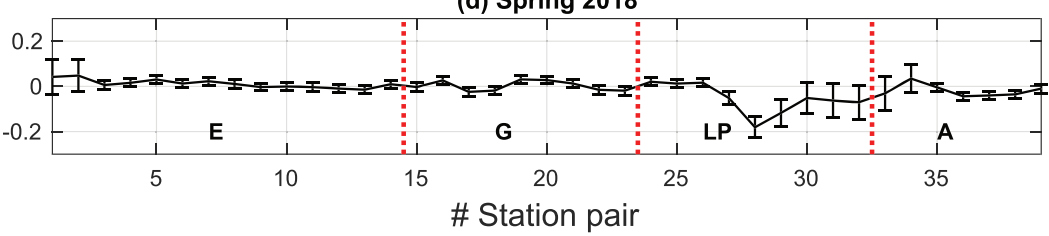

Figure 6. Velocities at the reference layer from the inverse box model including error bars with the uncertainty (in $\mathrm{m} /$ s) for (a) fall 2016, (b) fall 2017, (c) spring 2017, and (d) spring 2018. The red dotted lines separate discrete transects, with transect name indicated in black capital letter. Positive velocities are north/east, and negative velocities are south/west. 
Table 3

Mass Transport Imbalances and Uncertainties (in Sv), After Adjustment Using Velocities Resulting From the Inverse Model for Each Enclosed Volumes

\begin{tabular}{ccccc}
\hline & Fall 2016 & Fall 2017 & Spring 2017 & Spring 2018 \\
\hline Box 1 & LP-A & F-E & LP-A & E-G-LP \\
& $0.1 \pm 0.2$ & $0.2 \pm 0.3$ & $-0.2 \pm 0.2$ & $0.2 \pm 0.2$ \\
Box 2 & A-B & E-LP-G & A-B & LP-A \\
& $-0.2 \pm 0.2$ & $-0.1 \pm 0.3$ & $0.2 \pm 0-2$ & $-0.2 \pm 0.2$ \\
Box 3 & B-D-C & - & - & - \\
& $0.1 \pm 0.2$ & & & \\
\hline
\end{tabular}

Note. The enclosed volumes for boxes 1-3 are defined in Table 2 .
As we consider the mass conservation for each layer and in total, alongside errors, we solve the following equation:

$$
A b+n=-Y
$$

where $A$ is a matrix $M$ (layers) $\times N$ (unknowns) of mass, $b$ is a column vector of length $N$ including the unknown adjusted velocities at the reference level and the coefficient of Ekman transport, $n$ is a vector of size $M$ with the noise of each equation, and $Y$ is a vector of length $M$ containing the initial unbalanced mass transport in each layer and total.

The Gauss-Markov method is applied to solve the inverse problem. This method produces a minimum error variance solution from the initial estimates of the unknowns (Wunsch, 1996). These initial estimates are expressed with variances of $(0.1 \mathrm{~Sv})^{2}$ for each layer and (1 Sv $)^{2}$ for the overall mass transport. The preliminary variance of the adjusted velocity at the reference level is $(8 \mathrm{~cm} / \mathrm{s})^{2}$ in the station pairs shallower than $600 \mathrm{~m}$ depth and $(2 \mathrm{~cm} / \mathrm{s})^{2}$ in the deepest station pairs. Both mass and velocity variances are chosen following Hernández-Guerra et al. (2017).

The adjusted velocities in the reference layer estimated from the inverse box models, together with the errors, are shown in Figure 6. All velocities are small and not significantly different from zero in the deepest areas (i.e., transects F, E, and G). In contrast, higher values are found for station pairs close to the coastal slope (i.e., transects LP and B). The adjusted Ekman transport from the inverse models is not different from initial estimates for any of the occupations. Table 3 shows the imbalance together with the uncertainties in each box following the inverse model. The imbalance in every box is not significantly different from zero after accounting for uncertainties. This indicates that mass is conserved in the enclosed volumes.

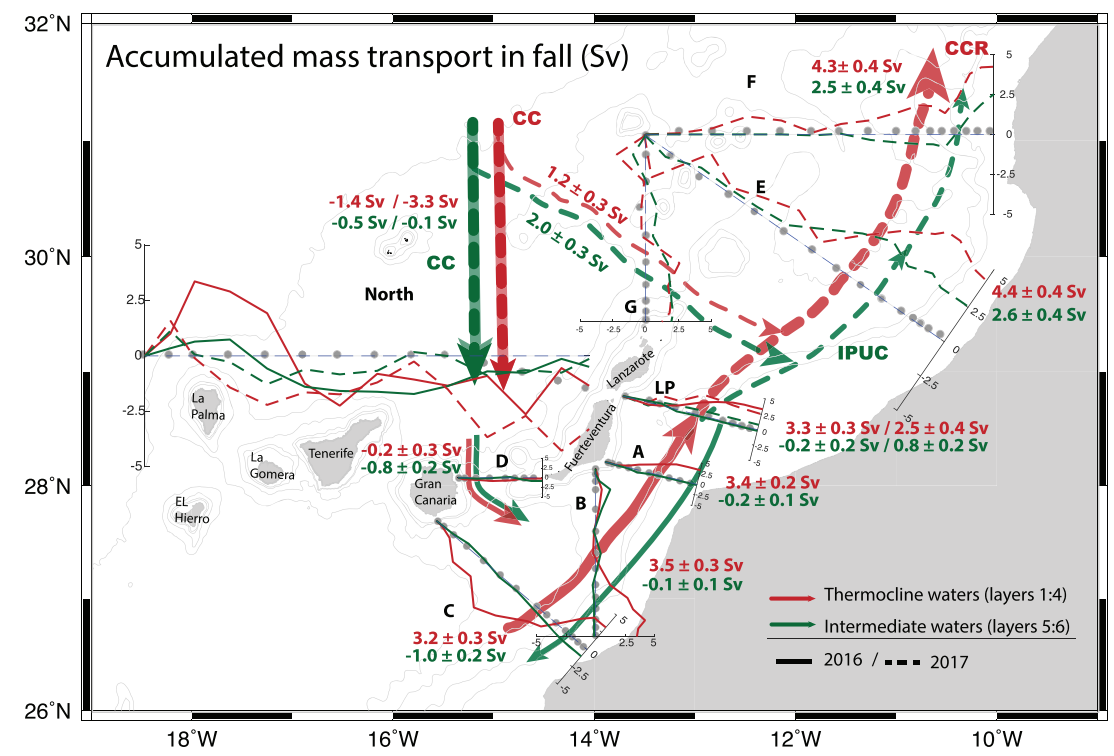

Figure 7. Representation of the accumulated mass transport (Sv) per section in fall. Transport is derived using velocities from the inverse box models output, except for the North section for which the LADCP-adjusted geostrophic transport is shown. The solid lines indicate 2016 data and the dashed lines 2017 data. Transport magnitudes, along with their uncertainties, are indicated for each line. When two values are shown, left values represent 2016 and right 2017. The transport of the thermocline layers ( 1 to 4 ) is represented in red and the intermediate transport (5 to 6) in green. Northward/eastward transport is positive, and southward/westward transport is negative. The arrows represent an idealized schematic representation of the adjusted geostrophic transport. The names of the currents are labeled next to the colored arrows, CC stands for the Canary Current, IPUC for the Intermediate Poleward UnderCurrent and CCR for the Canary Current Recirculation. 


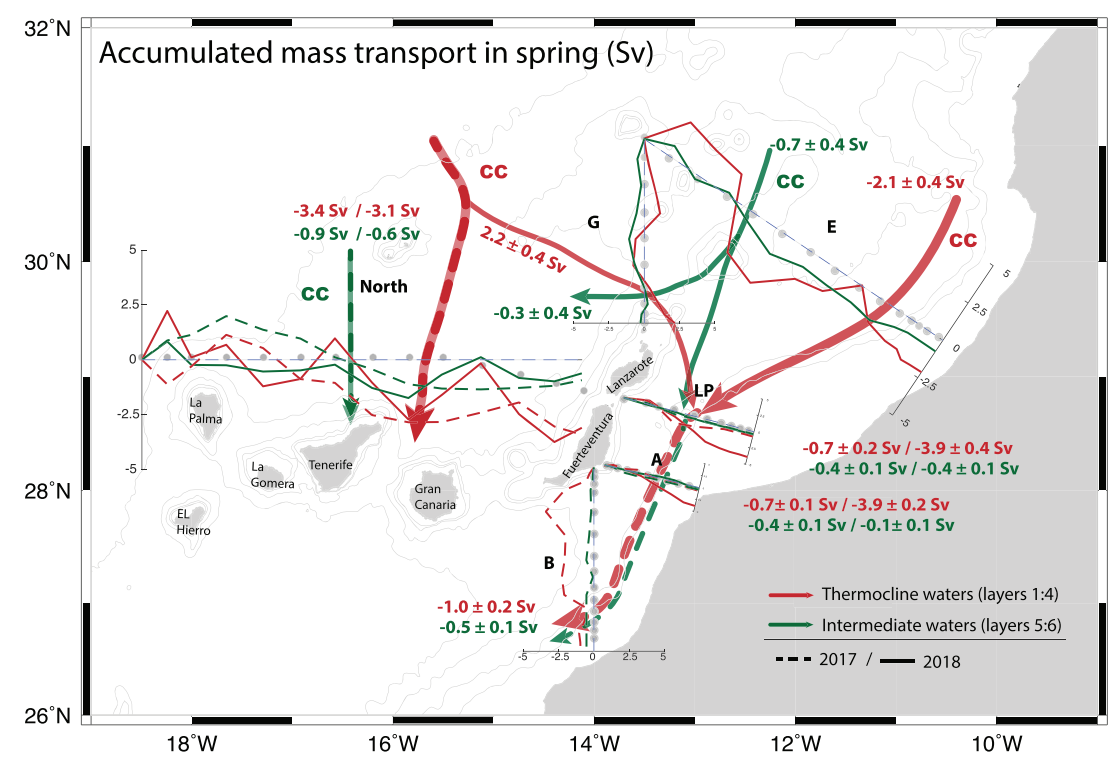

Figure 8. Same as Figure 7 for spring. Here values to the left correspond to 2017 and the right to 2018. The solid lines represent the transport for the 2018 cruise and the dashed lines the transport for 2017.

\section{Final Geostrophic Transport}

Figures 7 and 8 show a schematic representation of the flow in fall and spring, respectively, together with the accumulated mass transport of each hydrographic section derived from velocities of both, LADCP data and inverse models. LADCP-adjusted geostrophic transport of the North section, for which we could not apply the inverse box models, is also shown in Figures 7 and 8 in order to improve our understanding of the circulation through the Canary Archipelago. The net transport across each section as well as the unbalanced transport at the north section is presented in Table 4. In order to maintain a sign convention between the initial and final transport, the inverse model adjusted results are shown with geographic sign, with northward/eastward transports

Table 4

Net Transport Together With Their Uncertainties (in Sv) per Section and Cruise at the Thermocline and the Intermediate Levels

\begin{tabular}{lccccc}
\hline \multirow{2}{*}{ Section } & Layer & Fall 2016 & Fall 2017 & Spring 2017 & Spring 2018 \\
\hline \multirow{2}{*}{ North } & Thermocline & -1.4 & -3.3 & -3.4 & -3.1 \\
& Intermediate & -0.5 & -0.1 & -0.9 & -0.6 \\
LP & Thermocline & $3.3 \pm 0.3$ & $2.5 \pm 0.4$ & $-0.7 \pm 0.2$ & $-3.9 \pm 0.2$ \\
& Intermediate & $-0.2 \pm 0.2$ & $0.8 \pm 0.2$ & $-0.4 \pm 0.2$ & $-0.4 \pm 0.1$ \\
$\mathrm{~A}$ & Thermocline & $3.4 \pm 0.2$ & - & $-0.7 \pm 0.2$ & $-3.9 \pm 0.2$ \\
& Intermediate & $-0.2 \pm 0.1$ & - & $-0.4 \pm 0.1$ & $-0.1 \pm 0.1$ \\
$\mathrm{~B}$ & Thermocline & $3.5 \pm 0.3$ & - & $-1.0 \pm 0.2$ & - \\
& Intermediate & $-0.1 \pm 0.1$ & - & $-0.5 \pm 0.1$ & - \\
$\mathrm{C}$ & Thermocline & $3.2 \pm 0.3$ & - & - & - \\
& Intermediate & $-1.0 \pm 0.2$ & - & - & - \\
$\mathrm{D}$ & Thermocline & $-0.2 \pm 0.3$ & - & - & - \\
& Intermediate & $-0.8 \pm 0.2$ & - & - & - \\
$\mathrm{E}$ & Thermocline & - & $4.4 \pm 0.4$ & - & $-2.1 \pm 0.4$ \\
& Intermediate & - & $2.6 \pm 0.4$ & - & $-0.7 \pm 0.4$ \\
$\mathrm{~F}$ & Thermocline & - & $4.3 \pm 0.4$ & - & - \\
\multirow{2}{*}{$\mathrm{G}$} & Intermediate & - & $2.5 \pm 0.4$ & - & - \\
& Thermocline & - & $1.2 \pm 0.3$ & - & $2.2 \pm 0.4$ \\
& Intermediate & - & $2.0 \pm 0.3$ & - & $-0.3 \pm 0.4$ \\
\hline
\end{tabular}

Note. The transport of the north section is not presented with uncertainties as it is only estimated with the LADCP data.

Abbreviation: LADCP: Lower Acoustic Doppler Current Profiler. positive and southward/westward transport negative.

\subsection{Fall}

In fall, the CC flows southward through the North section transporting thermocline waters at a rate of $-1.4 \mathrm{~Sv}$ and $-3.3 \mathrm{~Sv}$ in 2016 and 2017, respectively (Figure 7). This transport is in the same ranges as those previously estimated by Hernández-Guerra et al. (2017), Machín et al. (2006), and Vélez-Belchí et al. (2017). The main path of the $\mathrm{CC}$ in the northern sections is through the western area, although it is difficult to infer its exact position from hydrographic data as result of high mesoscale activity. However, satellite altimetry data from Copernicus (http://marine.copernicus.eu) provide insight into the position of the $\mathrm{CC}$ (Figure 9). In altimetry data, the westward flowing $\mathrm{AC}$ is clearly delineated from 33 to $36^{\circ} \mathrm{N}$ (Comas-Rodríguez et al., 2011). According to Pérez-Hernández et al. (2013), the AC is the current feeding the CC. The CC flows on the western side of the archipelago in 2016, while it is located between the islands of La Palma and Fuerteventura in 2017. In 2016, part of the southward flowing CC is trapped in two mesoscale eddies located at $30^{\circ} \mathrm{N}-14^{\circ} \mathrm{W}$ and $29^{\circ} \mathrm{N}-19^{\circ} \mathrm{W}$. Between Gran Canaria and Fuerteventura (section D), the CC appears as a small southward flow, with a transport not significantly different of zero $(-0.2 \pm 0.3 \mathrm{~Sv})$ in the thermocline layers (Figure 7). Other studies have showed that most of the CC 
Fall 2016
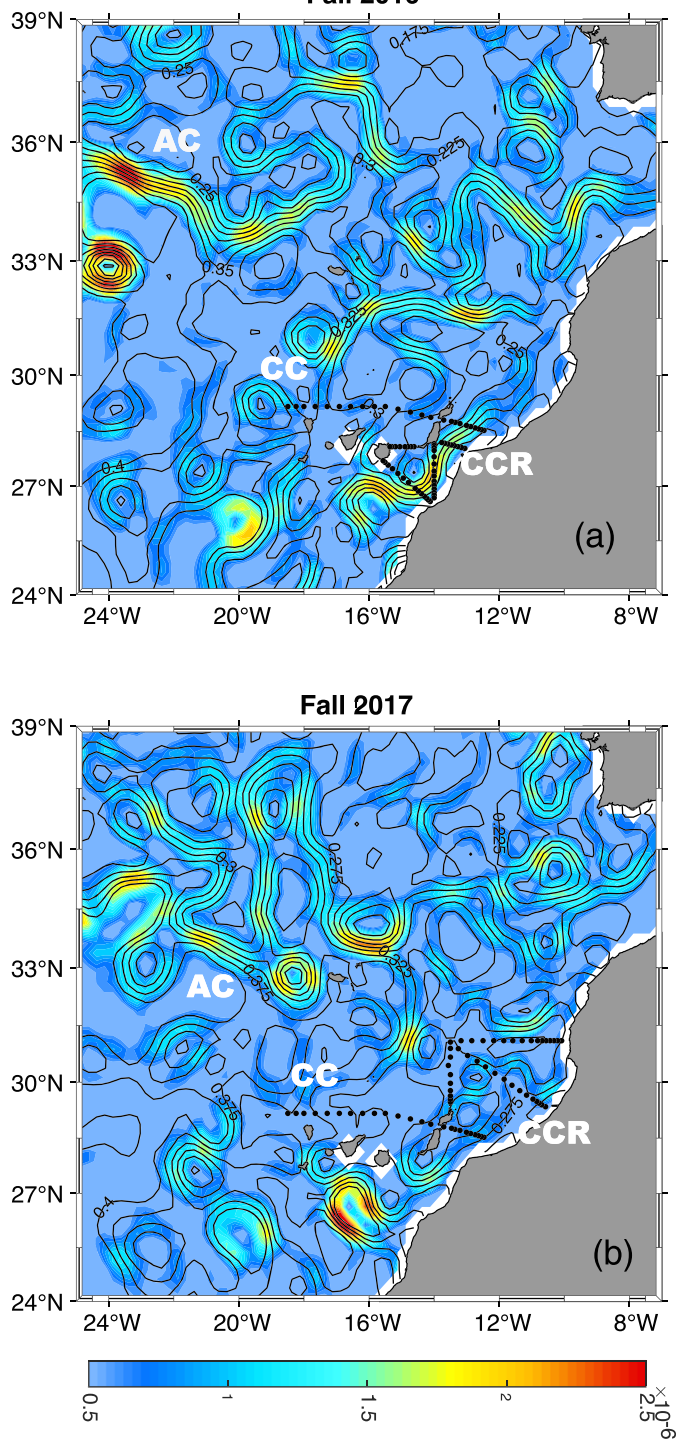
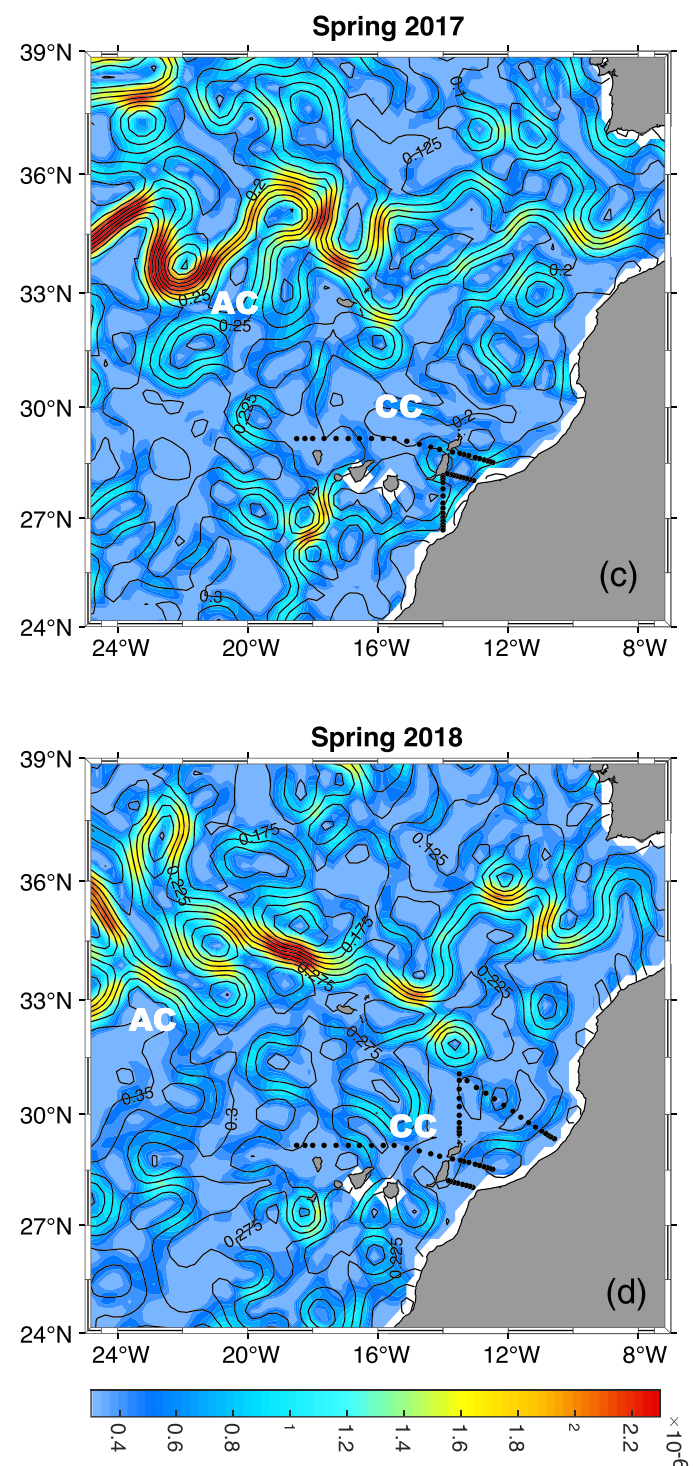

Figure 9. Maps of the gradient of absolute dynamic topography (ADT, colored contours) overlapped with ADT in meters (black labeled contours) for (a) fall 2016, (b) fall 2017, (c) spring 2017, and (d) spring 2017. Note the differences in the colorbar between fall and spring. The Azores Current (AC), the Canary Current Recirculation (CCR), and the Canary Current (CC) are labeled in white.

flows southward through the westernmost islands (Machín et al., 2006; Vélez-Belchí et al., 2017) or even west of La Palma in fall (Pérez-Hernández et al., 2013). South of Gran Canaria and Fuerteventura, the CC recirculates northward over the African slope, as observed in sections $\mathrm{C}$ and $\mathrm{B}$, carrying mass transports of $3.2 \pm 0.3 \mathrm{~Sv}$ and $3.5 \pm 0.3 \mathrm{~Sv}$, respectively (Figures 8 and $9 \mathrm{a}$ and $9 \mathrm{~b}$ ).

In section A (carried out in 2016), the recirculation of the CC transports $3.4 \pm 0.2 \mathrm{~Sv}$, on part with transport through the LP during the same year $(3.3 \pm 0.3 \mathrm{~Sv})$. However, the transport of the CC recirculation through the LP is slightly lower $(2.5 \pm 0.4 \mathrm{~Sv})$ in 2017 than in 2016. In 2017, north of Lanzarote, a small fraction of the CC $(1.2 \pm 0.3 \mathrm{~Sv})$ diverts eastward and enters the box through section $\mathrm{G}$ (Figure 7). This flow merges with the northward flowing CC. As a result, the CC recirculation through sections $\mathrm{E}$ and $\mathrm{F}$ is higher than that at the $\mathrm{LP}(4.4 \pm 0.4 \mathrm{~Sv}$ and $4.3 \pm 0.4 \mathrm{~Sv}$, respectively). Mesoscale features are apparent in all sections, as shown in the accumulated mass transport diagrams (Figure 7), which could impact the accuracy of these estimates. 
Table 5

Mass Transport (Sv) Through the Lanzarote Passage in Fall, Spring, and for the Seasonal Cycle

\begin{tabular}{llrcc}
\hline Year & \multicolumn{1}{c}{ Layers } & \multicolumn{1}{c}{ Fall } & \multicolumn{1}{c}{ Spring } & Seasonal cycle \\
\hline \multirow{2}{*}{ 2016-2017 } & Thermocline (1:4) & $3.3 \pm 0.3$ & $-0.7 \pm 0.2$ & $4.0 \pm 0.5$ \\
& Intermediate (5:6) & $-0.2 \pm 0.2$ & $-0.4 \pm 0.2$ & $0.2 \pm 0.4$ \\
& Net (1:6) & $3.1 \pm 0.3$ & $-1.1 \pm 0.1$ & $4.2 \pm 0.4$ \\
\multirow{2}{*}{$2017-2018$} & Thermocline (1:4) & $2.5 \pm 0.4$ & $-3.9 \pm 0.2$ & $6.4 \pm 0.6$ \\
& Intermediate (5:6) & $0.8 \pm 0.2$ & $-0.4 \pm 0.1$ & $1.2 \pm 0.3$ \\
\multirow{2}{*}{2017} & Net (1:6) & $3.2 \pm 0.4$ & $-4.3 \pm 0.2$ & $7.6 \pm 0.6$ \\
& Thermocline (1:4) & $2.5 \pm 0.4$ & $-0.7 \pm 0.2$ & $3.2 \pm 0.4$ \\
& Intermediate (5:6) & $0.8 \pm 0.2$ & $-0.4 \pm 0.2$ & $1.2 \pm 0.3$ \\
& Net (1:6) & $3.3 \pm 0.4$ & $-1.1 \pm 0.3$ & $4.4 \pm 0.5$ \\
\hline
\end{tabular}

Note. The CC, the intermediate water transport, and the net transport between the $\mathrm{CC}$ and the intermediate layers are shown.
In fall, the IPUC at intermediate levels show a southward transport in the North section with values of -0.5 and $-0.1 \mathrm{~Sv}$ in 2016 and 2017, respectively, indicative of interannual variability (Figure 7). Through the passage between Gran Canaria and Fuerteventura, the intermediate waters show a southward transport of $-0.8 \pm 0.2 \mathrm{~Sv}$, similar to that of the North section in 2016. Over the African slope, the flow at intermediate waters shows high interannual variability, as the IPUC is only identifiable in 2017. From the LP to F, the transport of the northward flowing IPUC is similar to that previously described by Hernández-Guerra et al. (2017). Transport of the IPUC through the LP is $0.8 \pm 0.2 \mathrm{~Sv}$. This flow receives a contribution of $2.0 \pm 0.3 \mathrm{~Sv}$ entering the box through section $\mathrm{G}$, flowing northward over the African slope at a rate of $2.6 \pm 0.4$ and $2.5 \pm 0.4 \mathrm{~Sv}$ through sections $\mathrm{E}$ and $\mathrm{F}$, respectively. In contrast to 2017 , the intermediate flow in 2016 do not follow the same path as the thermocline waters. Sections A, B, and C, carried out in 2016, show a westward/southward transport close to the African slope of $-0.2 \pm 0.1 \mathrm{~Sv},-0.2 \pm 0.2 \mathrm{~Sv}$, and $-1.0 \pm 0.2 \mathrm{~Sv}$, respectively. Transport at A and B is small $(-0.2 \pm 0.1$ and $-0.1 \pm 0.1 \mathrm{~Sv}$ for $\mathrm{A}$ and $\mathrm{B}$, respectively), suggesting that the flow at $\mathrm{C}$ is mainly a contribution from section D.

\subsection{Spring}

During spring, in the thermocline, the CC flows southward through the North section and through the passage between the Canary Islands and the African coast. In 2018, the CC seems to be more constrained to the eastern islands (Figures 9c and 9d). The CC flows southward through the North section with a transport estimated in -3.4 Sv and -3.1 Sv in 2017 and 2018, respectively (Figure 8). The mass transport derived from box models shows that a branch of the $\mathrm{CC}$ enters the African slope through sections $\mathrm{E}(-2.1 \pm 0.4 \mathrm{~Sv})$ and $\mathrm{G}$ $(2.2 \pm 0.4 \mathrm{~Sv})$. Mesoscale structures are apparent in the western and northern portions of sections $\mathrm{E}$ and $\mathrm{G}$ (Figure 8), which could affect the accuracy of inferred mass transport. The CC flows southward through the LP and section A, with flow characterized by high interannual variability. In 2017 the transport is much smaller than in $2018(-0.7 \pm 0.2 \mathrm{~Sv}$ versus $-3.9 \pm 0.2 \mathrm{~Sv}$ in $\mathrm{LP}$, and $-0.7 \pm 0.1 \mathrm{~Sv}$ versus $3.9 \pm 0.4 \mathrm{~Sv}$ in $\mathrm{A}$, respectively). Despite the high variability between years, the estimated transport is consistent with previous estimates (i.e., Knoll et al. (2002); Laiz et al. (2012); Vélez-Belchí et al. (2017)). In section B, south of Fuerteventura, the CC mass transport is $-1.0 \pm 0.2 \mathrm{~Sv}$, although the presence of a cyclonic eddy, carrying a mass transport of $-4.6 \pm 0.5 \mathrm{~Sv}$, potentially affects our estimations.

The intermediate waters in spring flow southward through the North section, with a transport of $-0.9 \mathrm{~Sv}$ in 2017 and $-0.6 \mathrm{~Sv}$ in 2018 (Figure 8). Between the islands and the African shelf, the mass transport is southward. In 2018, the current enters the passage through section $\mathrm{E}(-0.7 \pm 0.4 \mathrm{~Sv})$ and a portion of it exits through section $\mathrm{G}(-0.3 \pm 0.4 \mathrm{~Sv})$, with the remainder flowing south through the LP $(-0.4 \pm 0.1 \mathrm{~Sv})$ and A sections $(-0.1 \pm 0.1 \mathrm{~Sv}$; Figure 8$)$. In contrast to the thermocline waters, the transport of intermediate waters in both years is similar. In 2017, the transport estimates are $-0.4 \pm 0.1 \mathrm{~Sv}$ in the LP, $-0.4 \pm 0.1 \mathrm{~Sv}$ in section $\mathrm{A}$, and $-0.5 \pm 0.1 \mathrm{~Sv}$ in section $\mathrm{B}$.

\subsection{Seasonal Cycle Amplitude}

Aside from interannual variability, differences in transport are apparent between fall and spring. We estimate the amplitude of the seasonal cycle in the LP, calculated as the difference between the fall transport of the precedent year minus the spring transport of the next year $\left(\right.$ Transport $_{\text {fall }}-$ Transport $_{\text {spring }}$ ), in order to compare with previous estimates by Vélez-Belchí et al. (2017) (Table 5).

The amplitude of the seasonal cycle for fall 2016-spring 2017 equal $4.2 \pm 0.34 \mathrm{~Sv}$, comparable to an amplitude of $3.7 \pm 0.4 \mathrm{~Sv}$ estimated by Vélez-Belchí et al. (2017) for the Eastern Boundary (EB). Unlike for 2016-2017, the amplitude for fall 2017-spring 2018 is higher, equaling $7.6 \pm 0.6 \mathrm{~Sv}$, a value comparable in magnitude to that estimated by Pérez-Herández et al. (2015) for the Atlantic basin at $26^{\circ} \mathrm{N}$. Estimating seasonal amplitude from 2017 data yields a value of $4.4 \pm 0.5 \mathrm{~Sv}$, on par with estimates from Vélez-Belchí et al. (2017). The high interannual variability in the net transport seasonal cycles results from high 
variability in spring transport (recall $-1.1 \pm 0.1 \mathrm{~Sv}$ and $-4.3 \pm 0.2 \mathrm{~Sv}$ in 2017 and 2018 , respectively), as fall transport is approximately similar in both years (Table 5).

\section{Discussion and Conclusions}

Mass transport has been inferred from two fall and two spring cruises carried out in the eastern North Atlantic Subtropical Gyre. Each cruise sampled the North section, and up to eight shorter sections that enclosed several volumes along the African slope which we use in an inverse box modeling framework to derive mass transport. The unbalanced initial geostrophic transport is adjusted with LADCP data and using results of an inverse box model (apart from the North section).

The intermediate water masses show strong seasonal and interannual variability. Spatially, while a core of MW/AAIW is apparent on the western/eastern side of the northernmost sections (E and F), further south (LP to B sections) only AAIW can be identified. Seasonally, the AAIW is the largest contributor to the seasonal cycle of intermediate waters. AAIW reaches its minimum salinities in fall, and MW reaches its maximum salinities in spring. The intermediate water masses also show variations on an interannual basis, particularly in spring. In spring, water masses at intermediate levels are saltier and warmer in 2018 than in 2017, showing a stronger/weaker MW/AAIW signal. In fall, the interannual difference in these water masses is smaller than in spring, although salinity shows values more extreme in 2017 than in 2016.

The circulation schemes shown in Figures 7 and 8 reveal different paths for the CC in fall and spring, as many authors have previously reported (i.e., Fraile-Nuez et al., 2010; Hernández-Guerra et al., 2003; Machín et al., 2006). In fall, the CC and the transport at intermediate levels flow southward through the western islands (Machín et al., 2006; Pérez-Hernández et al., 2013). The CC flows through the North section and section D, recirculating south of the archipelago due to mesoscale activity created by the islands, finally entering the channel between the eastern islands and Africa, as previously reported (Mason et al., 2011; Pérez-Herández et al., 2015). Interestingly, while the surface flow of the CC recirculates southwest of Gran Canaria, the intermediate flow travels between Gran Canaria and Fuerteventura. In 2017, a branch of the CC flows eastward $(1.2 \pm 0.3 \mathrm{~Sv})$ North of Lanzarote and joins the northward recirculation of the $\mathrm{CC}$, flowing over the African slope. As a result, the CC recirculation at the northernmost sections $\mathrm{E}$ and $\mathrm{F}$ $(4.4 \pm 0.4 \mathrm{~Sv}$ and $4.3 \pm 0.4 \mathrm{~Sv}$, respectively) is higher than at the LP $(2.5 \pm 0.4 \mathrm{~Sv})$. In fall, the CC demonstrates high interannual variability, with a mass transport 1.9 Sv weaker in 2016 than in 2017. We attribute this to the position of the current: while in 2017 the CC flows between La Palma and Fuerteventura, in 2016 the main path of the $\mathrm{CC}$ seems to lie west of the archipelago (Figures $8 \mathrm{a}$ and $8 \mathrm{~b}$ ), as in Pérez-Hernández et al. (2013), or appears diverted into large eddies.

As previously reported in the literature, the $\mathrm{CC}$ flows southward in spring in the oceanic region as well as over the African slope. Surprisingly, while in the oceanic region, the CC shows a steady transport of approximately $3 \mathrm{~Sv}$ across our sampling period, the CC branch flowing over the African slope demonstrates strong interannual variability, transporting $-3.9 \pm 0.4 \mathrm{~Sv}$ in 2018 versus $-0.7 \pm 0.2 \mathrm{~Sv}$ in 2017 . Hence, the easternmost path of the CC is found in 2018 (Figure 9d). The southward transport of 2017 is comparable to that previously estimated by Machín et al. (2006) for spring ( $-1.0 \pm 0.1 \mathrm{~Sv})$.

On the other hand, we observe highly variable northward/southward transport over the African slope in intermediate waters. The northward flowing IPUC, described by Hernández-Guerra et al. (2017), PérezHerández et al. (2015), and Vélez-Belchí et al. (2017), is only apparent in 2017. The absence of the IPUC in 2016 might be due to the seasonal intermittence, as discussed in Machín et al. (2010) who identified a northward IPUC/AAIW flow only from July to early October. Because our 2017 cruise took place in late October and early November, the IPUC may already have stopped, with the intermediate flow shifting southward.

The AMOC seasonality is strongly linked to the seasonality of the eastern boundary (Chidichimo et al., 2010; Kanzow et al., 2010; Pérez-Herández et al., 2015), with maximum northward transport for both, AMOC and eastern boundary, found in fall (Vélez-Belchí et al., 2017). The seasonal cycle in the eastern boundary results from variability in the CC and its recirculation in fall, as well as seasonal changes in the IPUC (Vélez-Belchí et al., 2017). Here we estimate that the flow through the LP varies seasonally and interannually, from $4.2 \pm 0.4 \mathrm{~Sv}$, in 2016-2017, to $7.6 \pm 0.6 \mathrm{~Sv}$, in 2017-2018. Transport for 2016-2017 is similar to the eastern 
boundary seasonal cycle amplitude of $3.7 \pm 0.4$ Sv estimated by Vélez-Belchí et al. (2017) using hydrographic data from 2013/2014 at the LP. In contrast, 2017-2018 values are more similar to the full AMOC seasonality of about $6 \mathrm{~Sv}$, as estimated by Pérez-Herández et al. (2015) using a mooring time series from 2006 to 2012.

In conclusion, we provide with the first integrated view of the circulation of the CC as it flows through the eastern islands and the African shelf in fall and spring. Over the African slope, we find high variability in seasonal and interannual mass transport in the $\mathrm{CC}$, with highest interannual variability observed in spring. The transport at intermediate levels also shows an interannual and seasonal variability, with the IPUC only detected in fall 2017.

\section{Acknowledgments}

This study has been performed as part of the Instituto Español de Oceanografía RAPROCAN project, the SAGA project (CRTI2018-100844-BC31) funded by the Ministerio de Ciencia, Innovación y Universidades and Feder and the BOUNDARY project (ProID2017010083) funded by RIS-3, PO Feder Canarias. The initial conditions for the wind data were collected from the NCEP Reanalysis Derived data (http://www.esrl.noaa. gov/psd/). Absolute dynamic topography data were obtained from Copernicus Marine Environment Monitoring Service (http://marine. copernicus.eu/). This article is a publication of the Unidad Océano y Clima of the Universidad de Las Palmas de Gran Canaria, a R\&D\&i CSIC-associate unit. This work has been completed as part of MC-M work at IOCAG, in the doctoral program in Oceanografía y Cambio Global. The first author would like to thank the Agencia Canaria the Investigación, Innovación y Sociedad de la Información (ACIISI) grant program of "apoyo al personal investigador en formación." The authors are especially grateful to Carmen Presas for her help at sea ensuring the quality of the data. The authors are also grateful to the captain and the crew of the R/V Ángeles Alvariño for their help at sea. Data from the RAPROCAN Project are available from http://seadata.bsh.de/

\section{References}

Amante, C., \& Eakins, B. W. (2009). ETOPO1 1 arc-minute global relief model: Procedures, data sources and analysis. NOAA Technical Memorandum NESDIS NGDC-24. National Geophysical Data Center, NOAA. https://doi.org/10.7289/V5C8276M[2020]

Benítez-Barrios, V. M., Pelegrí, J. L., Hernández-Guerra, A., Lwiza, K. M. M., Gomis, D., Vélez-Belchí, P., \& Hernández-León, S. (2011). Three-dimensional circulation in the NW Africa coastal transition zone. Progress in Oceanography, 91(4), 516-533. https://doi.org/ 10.1016/j.pocean.2011.07.022

Borges, R., Hernández-Guerra, A., \& Nykjaer, L. (2004). Analysis of sea surface temperature time series of the south-eastern North Atlantic. International Journal of Remote Sensing, 25(5), 869-891. https://doi.org/10.1080/0143116031000082442

Cana, L., Grisolía-Santos, D., \& Hernández-Guerra, A. (2020). A numerical study of a sea breeze at Fuerteventura Island, Canary Islands, Spain. Boundary-Layer Meteorology, 175(2), 277-296. https://doi.org/10.1007/s10546-020-00506-z

Casanova-Masjoan, M., Joyce, T. M., Pérez-Hernández, M., Vélez-Belchí, P., \& Hernández-Guerra, A. (2018). Changes across 66²W, the Caribbean Sea and the Western boundaries of the North Atlantic Subtropical Gyre. Progress in Oceanography, 168, 296-309. https://doi. org/10.1016/j.pocean.2018.09.013

Chidichimo, M. P., Kanzow, T., Cunningham, S. A., Johns, W. E., \& Marotzke, J. (2010). The contribution of eastern-boundary density variations to the Atlantic meridional overturning circulation at $26.5^{\circ}$ N. Ocean Science, 6(3), 2507-2553. https://doi.org/10.5194/osd-62507-2009

Comas-Rodríguez, I., Hernández-Guerra, A., Fraile-Nuez, E., Martínez-Marrero, A., Benítez-Barrios, V. M., Pérez-Hernández, M. D., \& Vélez-Belchí, P. (2011). The Azores Current System from a meridional section at $24.5^{\circ} \mathrm{W}$. Journal of Geophysical Research, $116, \mathrm{C} 09021$. https://doi.org/10.1029/2011JC007129

Comas-Rodríguez, I., Hernández-Guerra, A., \& McDonagh, E. L. (2010). Referencing geostrophic velocities using ADCP data referencing geostrophic velocities using ADCP data. Scientia Marina, 74(2), 331-338. https://doi.org/10.3989/scimar.2010.74n2331

Fischer, J., \& Visbeck, M. (1993). Deep velocity profiling with self-contained ADCPs. Journal of Atmospheric and Oceanic Technology, 10(5), 764-773. https://doi.org/10.1175/1520-0426(1993)010<0764:DVPWSC >2.0.CO;2

Fraile-Nuez, E., \& Hernández-Guerra, A. (2006). Wind-driven circulation for the eastern North Atlantic Subtropical Gyre from Argo data. Geophysical Research Letters, 33, L03601. https://doi.org/10.1029/2005GL025122

Fraile-Nuez, E., Machín, F., Vélez-Belchí, P., López-Laatzen, F., Borges, R., Benítez-Barrios, V., \& Hernández-Guerra, A. (2010). Nine years of mass transport data in the eastern boundary of the North Atlantic Subtropical Gyre. Journal of Geophysical Research, 115 , C09009. https://doi.org/10.1029/2010JC006161

Harvey, J. (1982). Ө-S relationships and water masses in the eastern North Atlantic. Deep Sea Research Part A, Oceanographic Research Papers, 29(8), 1021-1033. https://doi.org/10.1016/0198-0149(82)90025-5

Hernández-Guerra, A., Machín, F., Antoranz, A., Cisneros-Aguirre, J., Gordo, C., Marrero-Díaz, A., et al. (2002). Temporal variability of mass transport in the Canary Current. Deep-Sea Research Part II: Topical Studies in Oceanography, 49(17), 3415-3426. https://doi.org/ 10.1016/S0967-0645(02)00092-9

Hernández-Guerra, A., Arístegui, J., Cantón, M., \& Leo, N. (1993). Phytoplankton pigment patterns in the Canary Islands area as determined using Coastal Zone Colour Scanner data. International Journal of Remote Sensing, 14(7), 1431-1437. https://doi.org/10.1080/ 01431169308953977

Hernández-Guerra, A., Espino-Falcón, E., Vélez-Belchí, P., Dolores Pérez-Hernández, M., Martínez-Marrero, A., \& Cana, L. (2017). Recirculation of the Canary Current in fall 2014. Journal of Marine Systems, 174, 25-39. https://doi.org/10.1016/j. jmarsys.2017.04.002

Hernández-Guerra, A., Fraile-Nuez, E., Borges, R., López-Laatzen, F., Vélez-Belchí, P., Parrilla, G., \& Müller, T. J. (2003). Transport variability in the Lanzarote Passage (eastern boundary current of the North Atlantic subtropical Gyre). Deep-Sea Research Part I: Oceanographic Research Papers, 50(2), 189-200. https://doi.org/10.1016/S0967-0637(02)00163-2

Hernández-Guerra, A., Fraile-Nuez, E., López-Laatzen, F., Martínez, A., Parrilla, G., \& Vélez-Blechí, P. (2005). Canary Current and North Equatorial Current from an inverse box model. Journal of Geophysical Research, 110, C12019. https://doi.org/10.1029/2005JC003032

Hernández-Guerra, A., Joyce, T. M., Fraile-Nuez, E., \& Vélez-Belchí, P. (2010). Using Argo data to investigate the Meridional Overturning Circulation in the North Atlantic. Deep Sea Research Part I: Oceanographic Research Papers, 57(1), 29-36. https://doi.org/10.1016/j. dsr.2009.10.003

Hernández-Guerra, A., López-Laatzen, F., Machín, F., de Armas, D., \& Pelegrí, J. L. (2001). Water masses, circulation and transport in the eastern boundary current of the North Atlantic subtropical gyre *. Scientia Marina, 65(S1), 177-186. https://doi.org/10.3989/ scimar.2001.65s 1177

Hernández-Guerra, A., Pelegrí, J. L., Fraile-Nuez, E., Benítez-Barrios, V., Emelianov, M., Pérez-Hernández, M. D., \& Vélez-Belchí, P. (2014). Meridional overturning transports at 7.5N and 24.5N in the Atlantic Ocean during 1992-93 and 2010-11. Progress in Oceanography, 128, 98-114. https://doi.org/10.1016/j.pocean.2014.08.016

Hernández-Guerra, A., \& Talley, L. D. (2016). Meridional overturning transports at $30^{\circ} \mathrm{S}$ in the Indian and Pacific Oceans in 2002-2003 and 2009. Progress in Oceanography, 146, 89-120. https://doi.org/10.1016/j.pocean.2016.06.005

Hernández-Guerra, A., Talley, L. D., Pelegrí, J. L., Vélez-Belchí, P., Baringer, M. O., Macdonald, A. M., \& McDonagh, E. L. (2019). The upper, deep, abyssal and overturning circulation in the Atlantic Ocean at $30^{\circ} \mathrm{S}$ in 2003 and 2011. Progress in Oceanography, 176(July), 102136. https://doi.org/10.1016/j.pocean.2019.102136 
Kanzow, T., Cunningham, S. A., Johns, W. E., Hirschi, J. J. M., Marotzke, J., Baringer, M. O., et al. (2010). Seasonal variability of the Atlantic meridional overturning circulation at 26.5 N. Journal of Climate, 23(21), 5678-5698. https://doi.org/10.1175/2010JCLI3389.1

Knoll, M., Hernández-Guerra, A., Lenz, B., López Laatzen, F., Machín, F., Müller, T. J., \& Siedler, G. (2002). The Eastern Boundary Current system between the Canary Islands and the African Coast. Deep-Sea Research Part II: Topical Studies in Oceanography, 49(17), 3427-3440. https://doi.org/10.1016/S0967-0645(02)00105-4

Laiz, I., Pelegrí, J. L., Machín, F., Sangrá, P., Hernández-Guerra, A., Marrero-Díaz, A., \& Rodríguez-Santana, A. (2012). Eastern boundary drainage of the North Atlantic subtropical gyre. Ocean Dynamics, 62(9), 1287-1310. https://doi.org/10.1007/s10236-012-0560-6

Machín, F., Hernández-Guerra, A., \& Pelegrí, J. L. (2006). Mass fluxes in the Canary Basin. Progress in Oceanography, 70(2-4), 416-447. https://doi.org/10.1016/j.pocean.2006.03.019

Machín, F., \& Pelegrí, J. L. (2009). Northward penetration of Antarctic Intermediate Water off Northwest Africa. Journal of Physical Oceanography, 39(3), 512-535. https://doi.org/10.1175/2008JPO3825.1

Machín, F. J., \& Pelegrí, J. L. (2016). Interaction of Mediterranean water lenses with Antarctic intermediate water off Northwest Africa. Scientia Marina, 80(S1), 205-214. https://doi.org/10.3989/scimar.04289.06A

Machín, F., Pelegrí, J. L., Fraile-Nuez, E., Vélez-Belchí, P., López-Laatzen, F., \& Hernández-Guerra, A. (2010). Seasonal flow reversals of intermediate waters in the canary current system east of the Canary Islands. Journal of Physical Oceanography, 40(8), 1902-1909. https:// doi.org/10.1175/2010JPO4320.1

Mason, E., Colas, F., Molemaker, J., Shchepetkin, A. F., Troupin, C., McWilliams, J. C., \& Sangrà, P. (2011). Seasonal variability of the Canary Current: A numerical study. Journal of Geophysical Research, 116, C06001. https://doi.org/10.1029/2010JC006665

Mason, E., Colas, F., \& Pelegrí, J. L. (2012). A Lagrangian study tracing water parcel origins in the Canary Upwelling System. Scientia Marina, 76(S1), 79-94. https://doi.org/10.3989/scimar.03608.18D

Nykjær, L., \& van Camp, L. (1994). Seasonal and interannual variability of coastal upwelling along northwest Africa and Portugal from 1981 to 1991. Journal of Geophysical Research, 99(C7), 14,197-14,207. https://doi.org/10.1029/94JC00814

Pacheco, M. M., \& Hernández-Guerra, A. (1999). Seasonal variability of recurrent phytoplankton pigment patterns in the Canary Islands area. International Journal of Remote Sensing, 20(7), 1405-1418. https://doi.org/10.1080/014311699212795

Pelegrí, J. L., Arístegui, J., Cana, L., González-Dávila, M., Hernández-Guerra, A., Hernández-León, S., et al. (2005). Coupling between the open ocean and the coastal upwelling region off northwest Africa: Water recirculation and offshore pumping of organic matter. Journal of Marine Systems, 54(1-4), 3-37. https://doi.org/10.1016/j.jmarsys.2004.07.003

Pérez-Herández, M. D., McCarthy, G. D., Vélez-Belchí, P., Smeed, D. A., Fraile-Nuez, E., \& Hernández-Guerra, A. (2015). The Canary Basin contribution to the seasonal cycle of the Atlantic Meridional Overturning Circulation at $26^{\circ} \mathrm{N}$. Journal of Geophysical Research: Oceans, 120, 7237-7252. https://doi.org/10.1002/2015JC010969

Pérez-Hernández, M. D., Hernández-Guerra, A., Fraile-Nuez, E., Comas-Rodríguez, I., Benítez-Barrios, V. M., Domínguez-Yanes, J. F., et al. (2013). The source of the Canary Current in fall 2009. Journal of Geophysical Research: Oceans, 118, 2874-2891. https://doi. org/10.1002/jgrc.20227

Roemmich, D., \& Wunsch, C. (1985). Two transatlantic sections: Meridional circulation and heat flux in the subtropical North Atlantic Ocean. Deep Sea Research Part A, Oceanographic Research Papers, 32(6), 619-664. https://doi.org/10.1016/0198-0149(85)90070-6

Skamarock, W. C., Klemp, J. B., Dudhia, J., Gill, D. O., Barker, D. M., Duda, M. G., et al. (2008). A Description of the Advanced Research WRF Version 3. Technical Report. https://doi.org/10.5065/D6DZ069T

Stramma, L., \& Schott, F. (1999). The mean flow field of the tropical Atlantic Ocean. Deep-Sea Research Part II, 46(1-2), 279-303. https:// doi.org/10.1016/S0967-0645(98)00109-X

Stramma, L., \& Siedler, G. (1988). Seasonal changes in the North Atlantic subtropical gyre. Journal of Geophysical Research, 93(C7), 8111. https://doi.org/10.1029/JC093iC07p08111

Tomczak, M. (1981). An analysis of mixing in the frontal zone of South and North Atlantic Central Water off North-West Africa. Progress in Oceanography, 10(3), 173-192. https://doi.org/10.1016/0079-6611(81)90011-2

Van Camp, L., Nykjaer, L., Mittelstaedt, E., \& Schlittenhardt, P. (1991). Upwelling and boundary circulation off Northwest Africa as depicted by infrared and visible satellite observations. Progress in Oceanography, 26(4), 357-402. https://doi.org/10.1016/00796611(91)90012-B

Vélez-Belchí, P., Pérez-Hernández, M. D., Casanova-Masjoan, M., Cana, L., \& Hernández-Guerra, A. (2017). On the seasonal variability of the Canary Current and the Atlantic Meridional Overturning Circulation. Journal of Geophysical Research: Oceans, 122, $4518-4538$. https://doi.org/10.1002/2017JC012774

Wunsch, C. (1996). The ocean circulation inverse problem. Journal of Fluid Mechanics, 352, 374-378. 